\title{
The Composition, Structure, and Origin of Carbonate Concretions Sampled in the South Kambalnyi Central Thermal Field, Kamchatka
}

\author{
S. N. Rychagov ${ }^{a, *}$, E. I. Sandimirova ${ }^{a}$, M. S. Chernov, **, O. V. Kravchenko ${ }^{a}$, and E. V. Kartasheva ${ }^{a}$ \\ ${ }^{a}$ Institute of Volcanology and Seismology, Far East Branch, Russian Academy of Sciences, \\ bulv. Piipa, 9, Petropavlovsk-Kamchatsky, 683006 Russia \\ ${ }^{b}$ Faculty of Geology, Moscow State University, Moscow, 119234 Russia \\ *e-mail:rychsn@kscnet.ru \\ **e-mail: chernov@geol.msu.ru
}

Received October 20, 2020; revised December 24, 2020; accepted March 23, 2021

\begin{abstract}
Carbonate concretions are formed at the base of a sequence of hydrothermal clay in the South Kambalnyi Central Thermal Field situated in the southern part of the Kambalnyi volcanic mountain range, Kamchatka. The concretions have complex chemical and mineral compositions: apart from aragonite which is the main component of each layer, the chemical compounds identified there include oxides of iron and silicon, sulfates of calcium and barium, sulfides of iron and other metals, carbonates of iron and manganese, siliceous ferromanganese formations, nitrogen compounds, and phosphates of calcium and rare metals. The concretions have diverse structures and textures that indicate a multiphase character of formation for these mineral aggregates. It is thought that their formation was due to the discharge of deep-seated alkaline metalliferous solutions in a zone of rock argillization of the South Kambalnyi Central Thermal Field.
\end{abstract}

Keywords: carbonate concretions, mineral aggregates, hydrothermal systems, thermal fields, acid environment, hydrothermal clay mass, alkaline metalliferous solutions

DOI: $10.1134 / \mathrm{S} 0742046321040059$

\section{INTRODUCTION}

Concretions or concretions (from the Latin concretio meaning condensing, congealing) are understood to be mineral bodies that are formed by material concentrating around rock fragments, organic remains, or other nucleii, and by successive growth of layers (zones) from center to periphery of a mineral aggregate. Concretions are sharply different from the surrounding mineral environment by composition and properties, consequently, they easily remain after rock disintegration, frequently making mineral deposits of the placer type (Geologicheskii slovar ..., 1973).

The concretions have different: 1) origin (diagenetic, epigenetic, metamorphic, metasomatic, sedimentary-hydrothermal, and hydrothermal); 2) composition (carbonate, siliceous, phosphoritic, baritic, sideritic, ferromanganese etc.); 3) texture (simple, composite, dense homogeneous, or bedded); 4) shape (globular, flattened, lenticular, columnar, conical etc.) (Atlas ..., 1969, 1988; Baturin, 1996; Vetoshkina, 2006; Gorbunova, 1958; Danilov, 1971; Zhelezo-margantsevye ..., 1986; Saltykov, 2008; Skiba, 1963; Sletov, 1977; Dietzel, 2000; Froelich et al., 1982). All of these provide evidence of a wide occurrence of concretions, which are indicators of the conditions of generation, alteration, and disintegration of rocks, sediments, and even soils.

In recent decades special attention has been paid to ferromanganese concretions of sedimentary hydrothermal origin; they are generally enriched in many metals, so can be used as polymetallic mineral deposits (Zhelezo-margantsevye ..., 1989; Kolesnik and Astakhova, 2018; Kolesnik and Kolesnik, 2013; Krasnov, 1995; Strakhov, 1974). Mineral concretions of the hydrothermal type proper are of less practical importance, and are less known, probably for that reason (Granina et al., 2010; Manceau et al., 2007). However, they can still supply rich information on the composition and conditions of discharge for metalliferous solutions, phases of mineral generation, and the evolution of the entire geothermal system (Rychagov et al., 2020b).

The present paper is devoted to a description of carbonate concretions found in the South Kambalnyi Central Thermal Field. They were first described as "pseudo-globular aragonite aggregates" (Karpov, 1970). No other publications dealing with these mineral objects are available, in spite of the fact that diverse research has been conducted in thermal fields of the Kambalnyi volcanic mountain range (Belousov et al., 1976; Ogorodova, 1974; Struktura ..., 1993). Our 


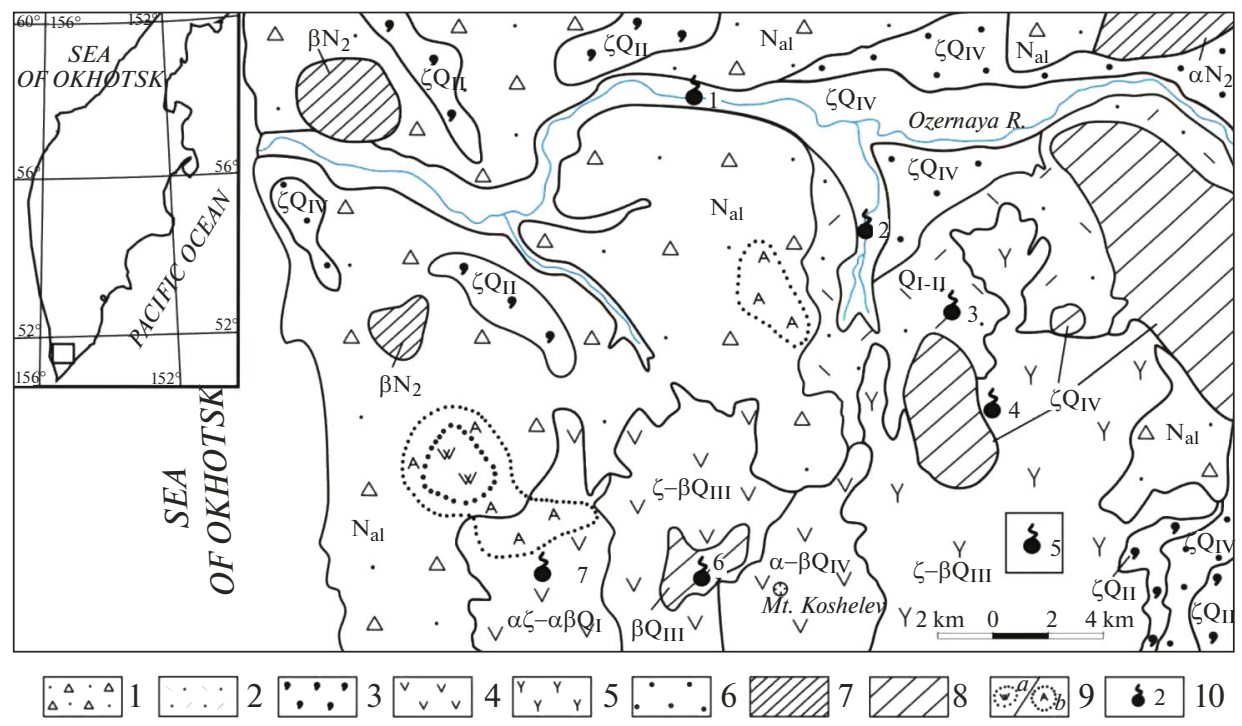

Fig. 1. A schematic geological map of the Pauzhetka-Kambalnyi-Koshelev geothermal (mineralization) area in southern Kamchatka. Based on materials of research and government-sponsored geological surveys to scale $1: 200000$. The inset shows the area of study in a larger setting. (1) pyroclastic lava deposits of the basement ( $\mathrm{N}_{\mathrm{al}}$, Alnean suite); (2) volcanogenic-sedimentary deposits $\left(\mathrm{Q}_{\mathrm{I}-\mathrm{II}}\right.$, Pauzhetka suite); (3) ignimbrites $\left(\mathrm{Q}_{\mathrm{II}}\right)$; (4) magmatic unit of the Koshelev volcanic massif: daciandesites - basaltic andesites in the western part $\left(\alpha \zeta-\alpha \beta \mathrm{Q}_{\mathrm{I}}\right)$, dacites - basalts in the central part $\left(\zeta-\beta \mathrm{Q}_{\mathrm{III}}\right)$, basaltic andesites in the eastern part $(\alpha-$ $\left.\beta \mathrm{Q}_{\mathrm{IV}}\right)$; (5) extrusive lava unit (the upper section) (from dacites to basalts) of the Kambalnyi volcanic mountain range $\left(\zeta-\beta \mathrm{Q}_{\mathrm{III}}\right)$; (6) pumice deposits of dacites and rhyolites $\left(\zeta \mathrm{Q}_{\mathrm{IV}}\right)$; (7) subvolcanic and extrusive bodies of intermediate and basic compositions $\left(\alpha \mathrm{N}_{2}, \beta \mathrm{N}_{2}\right)$; (8) same, with a contrasting composition ranging from basalts to dacites $\left(\beta \mathrm{Q}_{\mathrm{III}}, \zeta-\beta \mathrm{Q}_{\mathrm{III}}, \zeta \mathrm{Q}_{\mathrm{IV}}\right) ;(9)$ fields of secondary quartzites $(a)$ and of argillisites $(b)$ in the area of the Tretia Rechka paleo-hydrothermal system; (10) main geothermal anomalies and groups of thermal fields (1 Pervye Goryachie Klyuchi (Pionerlager), 2 Vtorye Goryachie Klyuchi (Pauzhetka hydrothermal system), 3 North Kambalnyi, 4 Central Kambalnyi, 5 South Kambalnyi (enclosed in a square as the object of study in the present paper), $6 \mathrm{Ve}$; rkhne-Koshelev, 7 Nizhne-Koshelev).

interest in these objects is due to the following reasons: 1) the concretions are not monomineral ones, they have a complex chemical composition; 2) they are formed at the base of a hydrothermal clay mass in the hottest area of the thermal field, so can serve as an indicator of localized discharges of an alkaline metalliferous solution by analogy with the East Pauzhetka thermal field (Rychagov et al., 2017b); 3) the textural and structural peculiarities of these concretions are very diverse, so they attract attention as collectible material.

\section{A SHORT DESCRIPTION OF THE SOUTH KAMBALNYI CENTRAL THERMAL FIELD}

This thermal field is situated in the southern Kambalnyi mountain range, which is a resurgent tectonomagmatic uplift in the structure of the Quaternary Pauzhetka volcano-tectonic depression (Dolgozhivushchii ..., 1980; Struktura ..., 1993) (Fig. 1). To the south the mountain range terminates in the active Kambalnyi volcano of basaltic composition (which is situated beyond the lower boundary, see Fig. 1) whose last eruption took place in March-April 2017 (Girina et al., 2017; Rychagov et al., 2017a). The volcanic range is composed of distinct stratovolcanoes, extrusions, and subvolcanic bodies of Pliocene to Pleistocene age ranging in composition between daciandes- ites and basalts (Belousov, 1978). The prevailing rocks are andesites that commonly show considerable hydrothermal alteration (Frolova et al., 2020). The only rocks that have not been altered are Late Quaternary basalts.

The Kambalnyi volcanic mountain range is characterized by intense geothermal activity (Nekhoroshev, 1959; Struktura ..., 1993; Sugrobov, 1979). There are three sets of thermal fields aligned along the axial part of the range at distances of 18-20 km: North, Central, and South Kambalnyi (Belousov et al., 1976). Each set probably represents a large present-day hydrothermal system. It is supposed that "distinct" hydrothermal systems of the Kambalnyi Range may have hydrodynamic connections and a single thermal and water recharge (Rychagov et al., 2017a, 2020a).

Special interest attaches to the set of the South Kambalnyi thermal fields situated at shortest distances $(7-8 \mathrm{~km})$ from the active volcano. This part of the mountain range includes a complex volcano, Termalnyi (Nekhoroshev, 1959) or North Kambalnyi (Syvorotkin, 1993), dating back to the Middle-Late Pleistocene and which is composed of daciandesites and basaltic andesites. The structure of this volcano is well described in the works of A.S. Nekhoroshev, V.I. Belousov, and V.L. Syvorotkin referred to above. The schematic geological map shown here has this volcano 


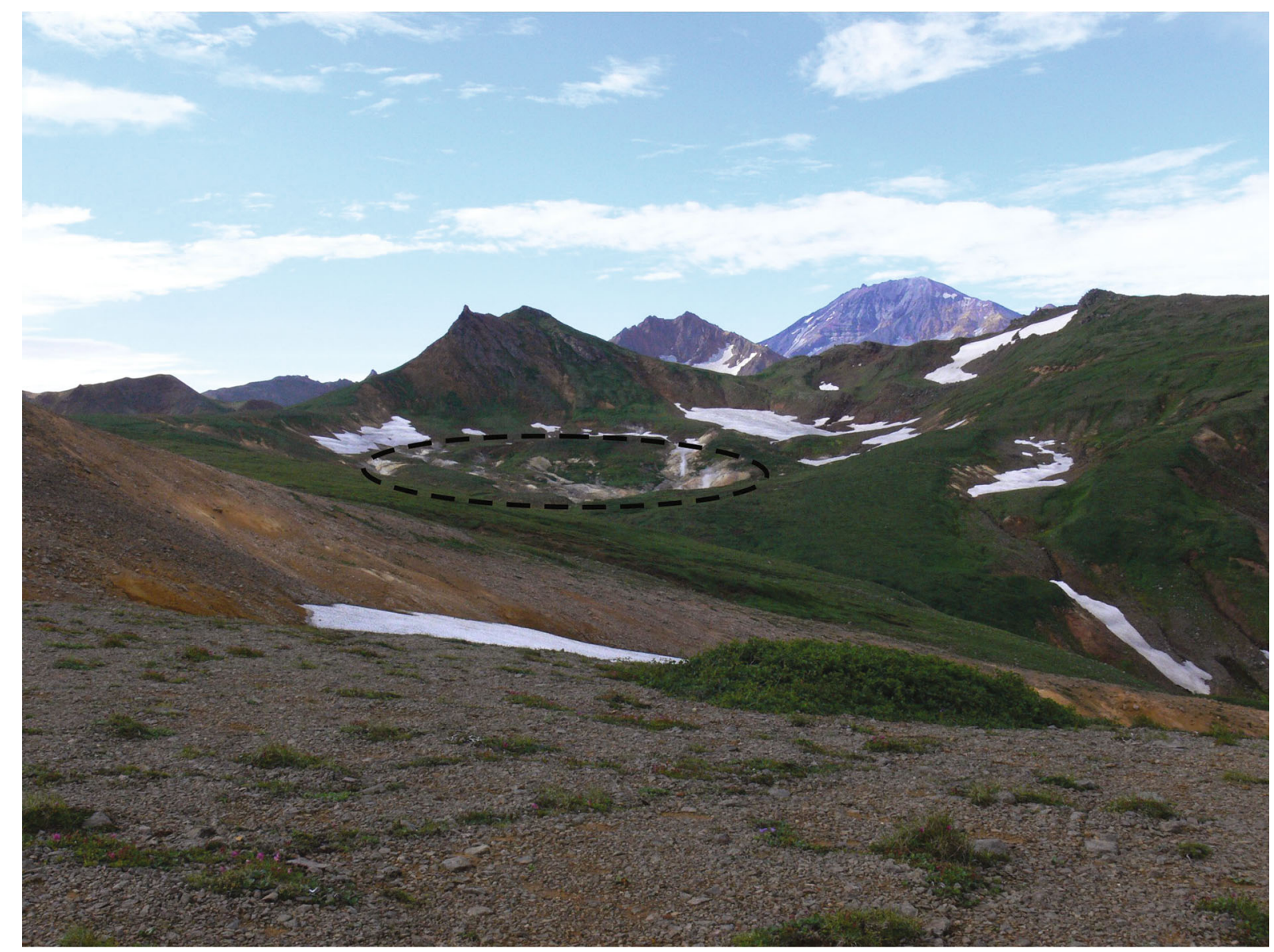

Fig. 2. The South Kambalnyi Central Thermal Field. In the background is Kambalnyi Volcano. The view is toward the south.

in a field of unstratified rocks (from dacites to basalts) at the Kambalnyi volcanic mountain range (marked 5 in Fig. 1). The set of the South Kambalnyi thermal anomalies includes three thermal fields: Dalnee, Tsentralnoe (Central), and Blizhnee. We are concerned with the Central Field here.

The South Kambalnyi Central Thermal Field (SKC) is confined to a circular morphostructure $\geq 1 \mathrm{~km}$ across (Fig. 2), which seems to be an eroded crater belonging to a cone of Termalnyi Volcano (North Kambalnyi). Basaltic andesite relics only slightly altered hydrothermally extend along the periphery of this morphostructure. The $600 \times 600$-m thermal field makes the central part of the edifice. Because of active erosion, including that due to geothermal processes acting on the relief, the field surface is intersected, and presents a radially concentric system of lows (brook valleys) and highs (small ridges). The most intense geothermal activity is concentrated over an area of about $150 \times 250 \mathrm{~m}$. The thermal occurrences include boiling aqueous and mud-water pots, pulsating springs, steam-gas jets, and steaming soils. The soils are composed of hydrothermal clays. The springs and soils had temperatures of $\leq 98-100^{\circ} \mathrm{C}$ at the diurnal surface. Unlike many other thermal anomalies in the Pauzhetka-Kambalnyi-Koshelev area, the SKC is characterized by contrasting physico-chemical conditions in the discharge zone of steam-charged hydrothermal occurrences: the water $\mathrm{pH}$ varies between $2.8-3.5$ and $7.5-8.0$ units, Eh is between +410 and -200 . The mineral content reaches $4 \mathrm{~g} / \mathrm{L}$, which too is not typical of surface discharges of thermal waters in the area (the total salinity is commonly below $0.8-$ $1.5 \mathrm{~g} / \mathrm{L}$ ). Large pots saturated with carbon dioxide and sulfur-bearing gases, and the pulsating springs in the middle of the field, are dominated by alkaline hydrocarbonate-sulfate ammonium (calcium-ammonium) waters. At the same time, springs with neutral and alkaline solutions alternate with acid springs.

The rocks that compose the thermal field are completely argillized. The hydrothermal clay mass is over $4 \mathrm{~m}$ thick and shows the classic zonal structure: one can see zones of sulfuric and carbon dioxide leaching (Rychagov et al., 2020a). The upper sulfuric leaching horizon consists of kaolinite-alunite clays with admixtures of opal, pyrite, Fe and Ti oxides, sulfates of $\mathrm{Ca}, \mathrm{Fe}$ and other metals. The lower horizon of carbon dioxide leaching is mostly composed of smectite- 

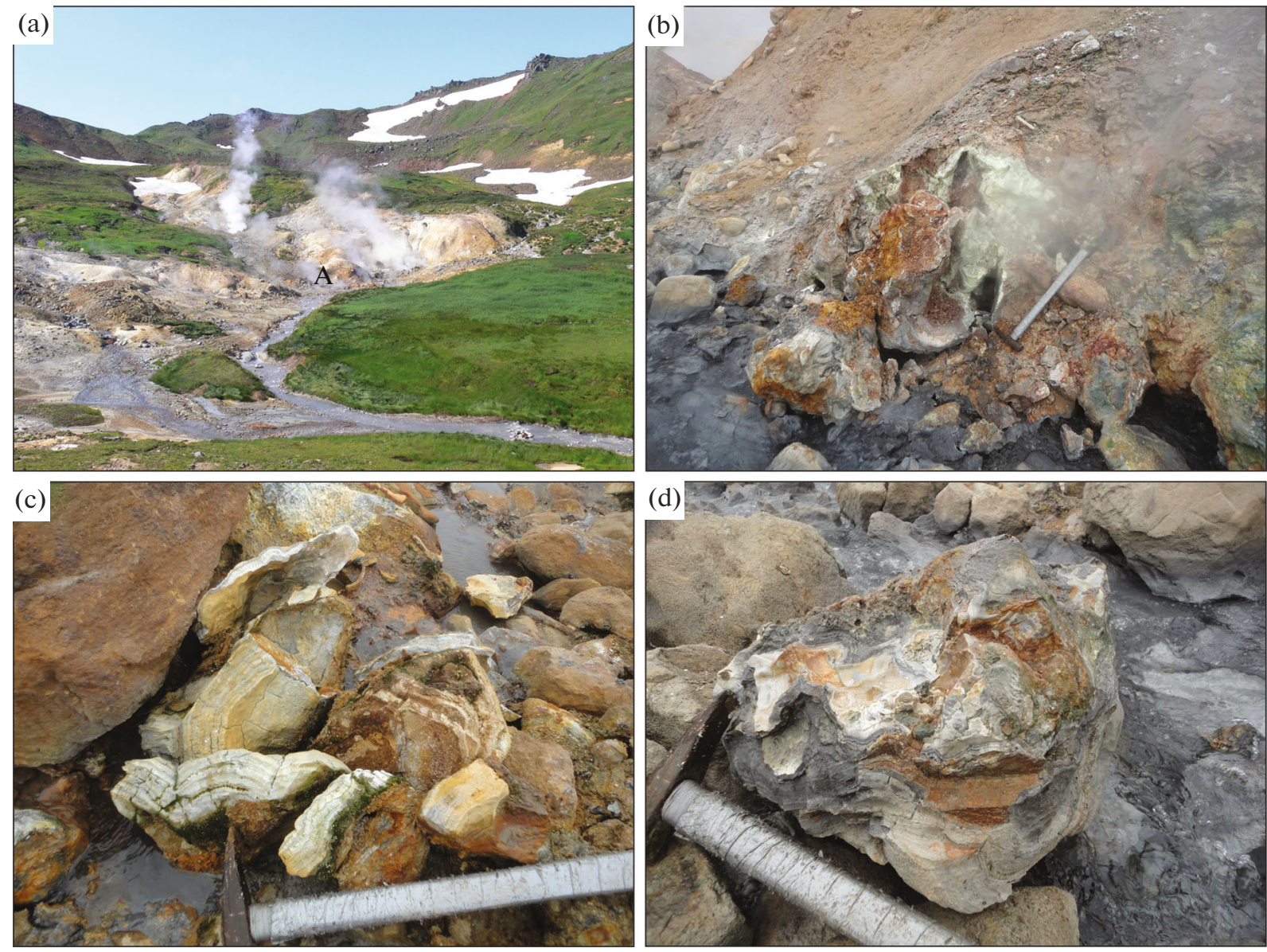

Fig. 3. The location and a general view of carbonate concretions sampled in the SKC. (a) a general view of the main discharge area of steam-charged hydrothermal fluids and the thermal ridge (A) where the concretions were formed; (b, c) concretion aggregates that are washed out from argillisites on both sides of the ridge; (d) a concretion whose hydrothermal clay has been cleaned away, $30-40 \mathrm{~cm}$ across.

group minerals (montmorillonite) and includes sulfides, sulfates, and carbonates of a number of metals (Ogorodova, 1974). The thickness of the clay horizons and layers varies strongly over different areas of the thermal field. A horizon of plastic clay 30 to $130 \mathrm{~m}$ has been reached in the top of the carbon dioxide leaching zone; the horizon can serve as an aquifer and a thermal screen, on analogy with the East Pauzhetka thermal field (Rychagov et al., 2017b). Three 2-m wells were drilled in the SKC hydrothermal clay to find oxides of $\mathrm{Si}, \mathrm{Fe}$, and $\mathrm{Ti}$, sulfates of $\mathrm{Ca}, \mathrm{Ba}, \mathrm{K}$, and $\mathrm{Al}$, carbonates of $\mathrm{Ca}, \mathrm{Fe}$, and $\mathrm{Mn}$, sulfides of $\mathrm{Fe}, \mathrm{Hg}$, $\mathrm{As}$, and $\mathrm{Sb}$ (Ogorodova, 1974). Our surveys showed that the deposits in the thermal field have a mineral composition of still greater diversity.

We have reviewed geophysical, general geological, mineralogical, and hydrogeochemical data to hypothesize that there is discharge of ascending mineralized alkaline thermal waters that are saturated with carbon dioxide and sulfur-bearing gases in the South Kambalnyi Central Thermal Field (Rychagov et al., 2020a, 2020b; Struktura ..., 1993; Feofilaktov et al., 2020).
However, these hydrothermal occurrences make local discharges upon the background of a widely abundant acid environment. It is known that the steam-gas jets and condensate waters of thermal solfataric fields are characterized by an abundance of dissolved carbon dioxide and hydrogen sulfide (Kononov, 1983; Pampura, 1985]. In addition, microorganisms are widely abundant at the surface and in the upper horizons of the hydrothermal clay mass (hydrogen, thionic, sulfuric microorganisms and iron bacteria) which exert an active oxidizing effect on sulfur compounds and which catalyze the formation of sulfate ion and sulfuric acid (Zavarzin, 1964; Zavarzin and Karpov, 1982). These studies emphasized the role of sulfate pore solutions in the formation of the sulfuric acid leaching zone in the hydrothermal clay mass and in the transformation of montmorillonite into smectite-kaolinite argillisites as the solutions were seeping into the lower carbon dioxide zone (Eroshchev-Shak, 1992). It thus appears that the discharge of alkaline hydrothermal fluids in the SKC area is not an ordinary phenomenon and is of interest from several different aspects, including min- 
eral generation under contrasting physico-chemical conditions.

\section{THE METHOD OF STUDY}

The method employed for the study of concretions included the following: 1) concretion sampling and sawing the samples into plates (a total of over 30 samples were used of which 15 have been studied); 2) a detailed description of the structure by means of total mineralogical analysis; 3) A study of chemical composition layer by layer using an S4 PIONEER X-ray fluorescence spectrometer; 4) determining the chemical and mineralogical compositions of the layers by microprobe surveys using a VEGA 3 electron scanning microscope equipped with an X-MAX 80 energy dispersive spectrometer; 5) determining the chemical and mineralogical compositions of layers by microprobe surveys using a LEO $1450 \mathrm{~V}$ scanning electron microscope equipped with an INCA 300 energy dispersive spectrometer. The studies were carried out at the Institute of Volcanology and Seismology (IV\&S), Far East Branch (FEB), Russian Academy of Sciences (RAS) and at Faculty of Geology, Moscow State University.

\section{RESULTS OF STUDIES}

The concretions make boulders of rounded or flattened shapes $15-20$ to $>50-70 \mathrm{~cm}$ across, and are washed out by brooks from under the base of the thermal ridge (Fig. 3). Most of the aggregates are nearly globular.

The thermal ridge has the shape of a wedge 5 to $20 \mathrm{~m}$ in cross section and $50 \mathrm{~m}$ long; it is composed of hydrothermal clays and is intensely disintegrating (is falling apart into blocks and slides down) under the action of boiling pots and steam-gas jets. We have not succeeded in finding the in situ positions of concretions, not even by drilling a well and by pitting because of a complex structure of the ridge (among other things, this includes hidden mud-water pots, large cavities, and open joints in the clay mass), high temperatures, and gas presence. We believe that the concretions make a definite horizon (a large lens or zone) at the base of the clay mass in this area of the SKC. No concretions have been detected elsewhere in the thermal field.

The concretions have diverse structures and textures (Fig. 4). Their structure is mostly concentrically zonal (see Figs. 4a, 4b). The core of a concretion contains andesite fragments, more frequently completely altered to become a quartz-smectite-chlorite aggregate with numerous pyrite and iron oxide crystals (see Fig. 4c). The middle of a concretion is generally characterized by crustification, colloform-banded, and globular structures, and is black to grey in color (see Figs. $4 \mathrm{~d}, 4 \mathrm{e}$ ). The layers have varying thickness ranging between a few tens of microns and $3-5 \mathrm{~cm}$. The light bands are mostly composed of "pure" calcium carbonate, the darker bands consist of $\mathrm{Ca}$ and $\mathrm{Mn}$ carbonates with an admixture of other minerals (see Figs. $4 \mathrm{f}-4 \mathrm{~h}$ ). One also observes small concretions of simple structure: slightly altered andesite fragments are overgrown with two to three carbonate bands (see Fig. 4i); such concretions must be the youngest.

The detailed studies were performed for two large concretions. The one is concretion SKC-Zh2/19 (Fig. 5). It was of great interest because its layers were easily separable from one another, permitting a study of both internal structure and layer surfaces. The groundmass of each layer was calcium carbonate, or aragonite (we did not carry out X-ray diffraction studies, but earlier ones are available (Karpov, 1970)). In addition to aragonite, all layers also include microzones and individual flakes, incrustations, kidney-shaped and globular sinters of a complex mineral composition. One can identify gypsum, barite, manganese carbonates, pyrite and marcasite, siliceous ferrous and ferromanganese aggregates, iron hydroxides, and nitrogen compounds (which are most likely minerals that contain ammonium), and others (Table 1). The elemental composition of the concretion layers is diverse as well (Table 2). Layer 1a is conspicuous in having increased concentrations of most components and a low value of calcium. For the other layers we see a prevalence of $\mathrm{Ca}$ with simultaneous high values of $\mathrm{Si}, \mathrm{Mn}, \mathrm{Mg}, \mathrm{P}$, and $\mathrm{S}$, which provides evidence of the presence of other mineral components in the carbonate groundmass as marked in Table 1. The high value of loss on ignition shows the presence of other volatiles apart from sulfur. The layer surfaces show phosphate films (dominated by F-calcium phosphate), the relief lows are filled with gypsum, siliceous ferrous and siliceous ferromanganese aggregates, smectite in association with gypsum and carbonate (Fig. 6). One notes a constant presence of phosphates, mostly as films or veinlets between zones of carbonate growth. The aragonite crystals have a porous structure and show traces of leaching at fracture surfaces.

Detailed microprobe studies revealed considerable inhomogeneities in the structure and composition of calcium carbonate interbeds (Fig. 7). The carbonate interbeds have a complex chemical composition (there are $\mathrm{Si}, \mathrm{Fe}, \mathrm{Al}, \mathrm{Mn}, \mathrm{Mg}, \mathrm{P}$ etc.) because of the formation of lenses, films and similar segregation forms of other minerals (see Figs. 7a, 7b). The groundmass is a well-crystallized Ca carbonate; it includes particles of smectites, siliceous ferrous and ferromanganese formations (see Fig. 7c). Fragments of microlayers are composed of aggregates of rounded particles having carbonate-phosphate-silicon-alumosilicate composition (see Fig. 7d). Individual globules of the same composition fill in pores in the carbonate groundmass (see Fig. 7e). Gypsum seems to frequently form during the terminal phases of layer formation (see Fig. 7f). The later phases also saw the deposition of $\mathrm{Cl}, \mathrm{Na}$, and $\mathrm{K}$ salts, which cover the surface of carbonate crystals in the form of overgrowth films and making filiform 

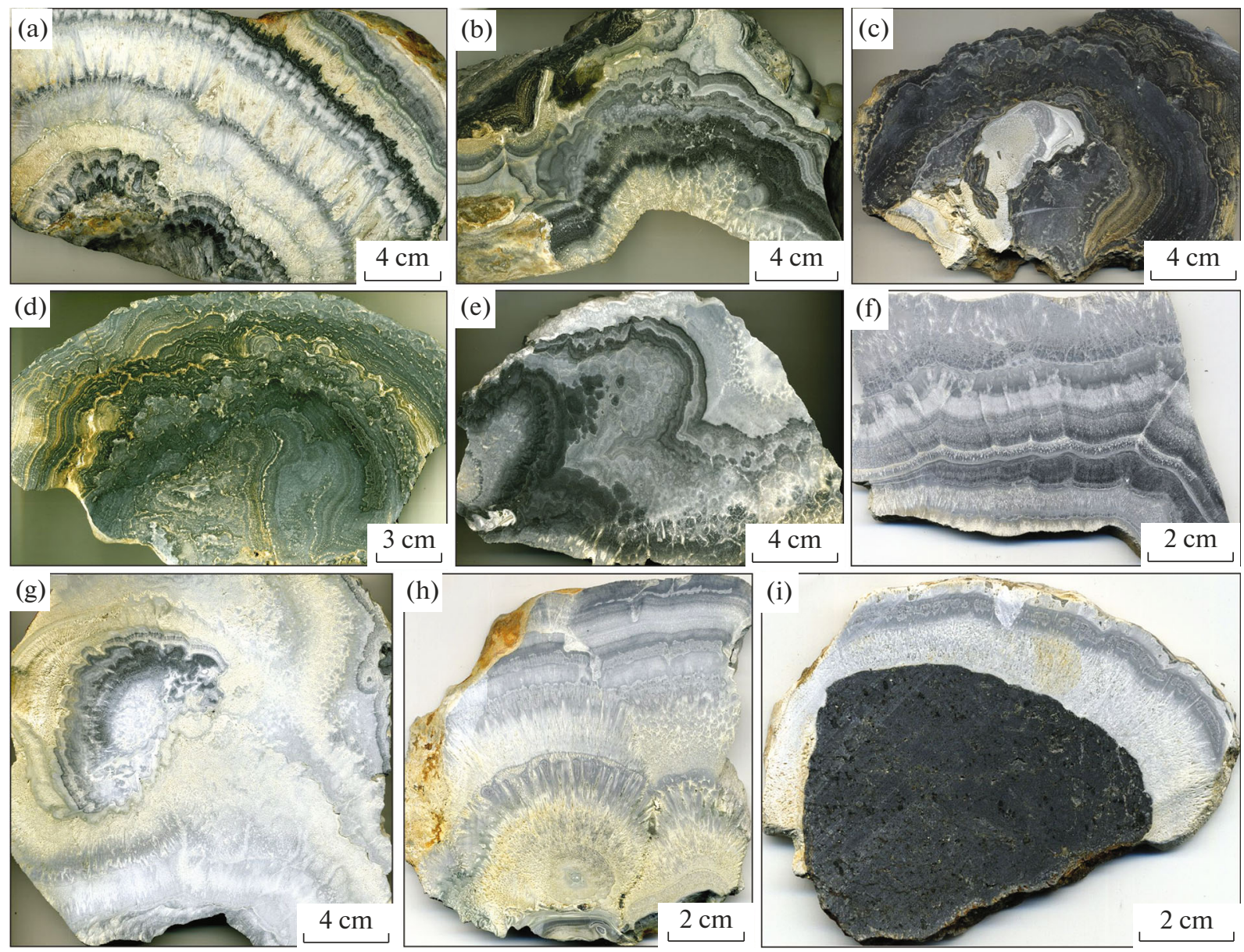

Fig. 4. The main types of structures and textures of carbonate concretions sampled in the SKC. For explanations see main text.

aggregates between the grains (see Fig. 7h). A wellcrystallized carbonate fills pores in the cryptocrystalline groundmass (see Figs. 7g, i).

The surface relief of the outer, ninth, layer is of great interest (Fig. 8): siliceous carbonate flakes make the sand dune sculpture (Lebedev, 1965). L.M. Lebedev carried out several fundamental studies in the mineral generation from colloid compounds of varying composition. He found out that the sand dune sculpture characterizes the spreading of a gel-like material over an inclined surface, with some individual structural elements being isolated from the rest to make a mud-flow and flakes. Each surface fragment like those described above has a zonal microstructure that reflects individual phases in gel crystallization. G.A. Karpov studied the sand dune sculpture of carbonate concretions to hypothesize that the direction of flow and the position of the thermal water source could be reconstructed for the South Kambalnyi Central Thermal Field (Karpov, 1970). There is undoubtedly a localized discharge of hydrothermal solutions in this area of the thermal field, as also supported by geoelectric studies in the SKC (Feofilaktov et al., 2020). However, one cannot unfortunately reconstruct the direction of thermal water flow, unless for the case where concretions are found in situ, which is as good as impossible for this part of the thermal field.

Seven layers were selected in the second concretion SKC-Zh6/19 to study their structure, chemical and mineral compositions (Fig. 9). The layers have distinct colors (from light grey to black-grey) and clear boundaries. The inner zone is a core of carbonate and siliceous carbonate composition (no. 1, see Fig. 9) and contains fragments of a completely argillized rock (no. 2). Between these one finds small siliceous carbonate lenses with large (up to 2-3 mm) crystals of pyrite and probably of other sulfides (nos. 1-2, see Fig. 9). The other layers make a concentrically zonal texture of the concretion. According to electron microscopy, the groundmass in each layer (nos. 3-6) is calcium carbonate (more likely this is aragonite). However, thin films or veinlets between the microlayers, in pores and in interstices between acicular calcium carbonate crystals contain other minerals: rhodochrosite, calcium phosphate, barite, pyrite, and calcium sulfates. The dark color of the layers is due to micro admixtures of $\mathrm{Mn}, \mathrm{Fe}, \mathrm{P}$, and finely dispersed pyrite. It is of interest to study how the elemental composition varies 

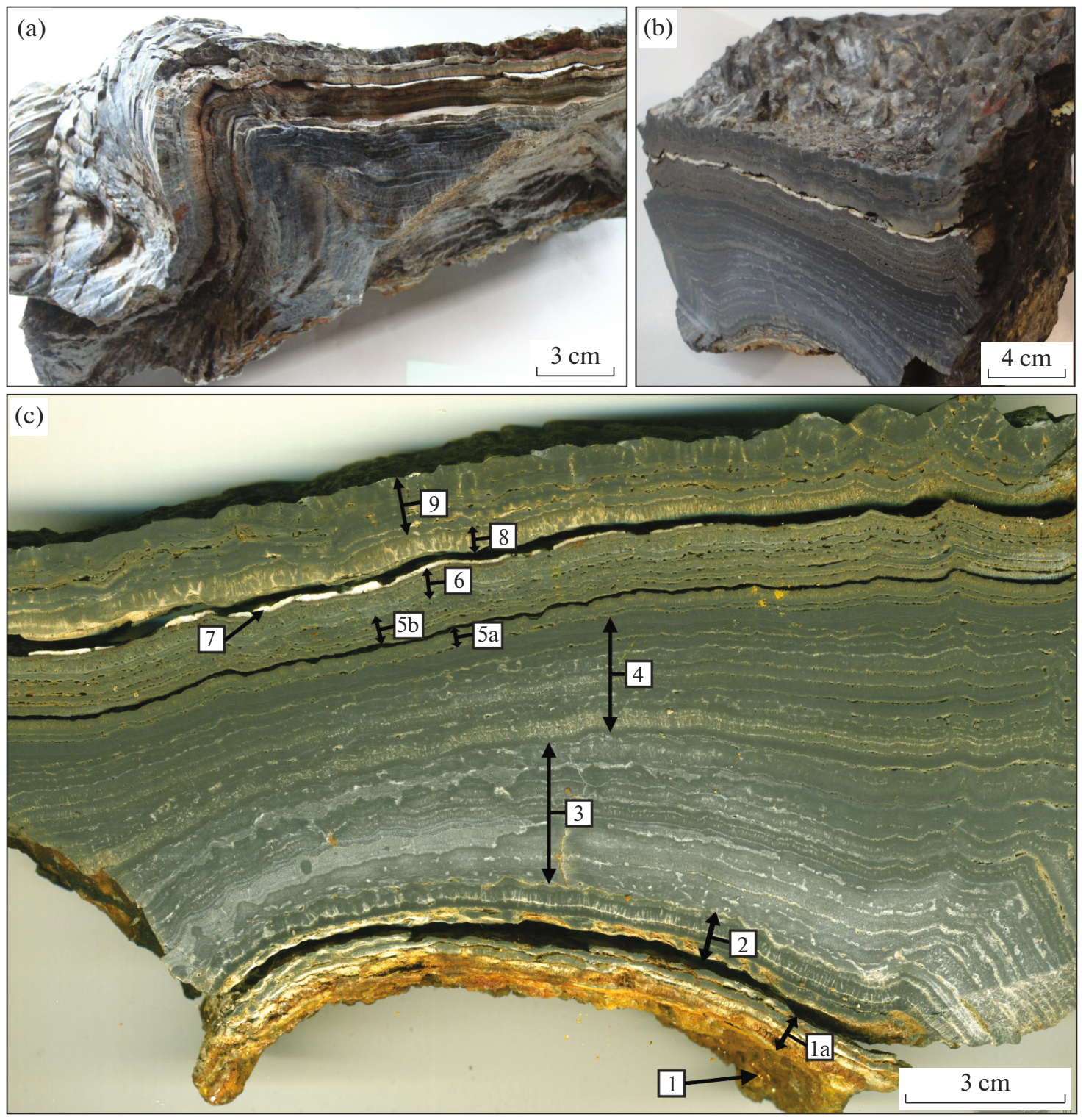

Fig. 5. Concretion SKC-Zh2/19. (a) general view; (b) specimen obtained by sawing the concretion across; (c) specimen for study (the vertical size of the plate is $12-13 \mathrm{~cm}$ ) and identification numbers of the layers (see Table 1).

between layers (Table 3, Fig. 10). Layers no. 1 and no. 1-2 contain, apart from $\mathrm{Ca}$, also $\mathrm{Si}, \mathrm{Fe}, \mathrm{Mn}, \mathrm{P}$, and $\mathrm{S}$ in amounts up to $1-10 \mathrm{wt} \%$. Layer no. 2 stands out because silicon prevails against calcium and because it has high iron values. This "layer" is argillized andesite that has been completely transformed into an aggregate of the following composition: smectite + chlorite + calcium carbonate + opal (chalcedony?) + pyrite (with sphalerite inclusions) + calcium phosphates. The next 4 layers have a uniform chemical composition dominated by $\mathrm{Ca}$. The relatively high concentrations of sulfur can be explained by the presence of pyrite in these layers occurring along aragonite crystals and between its layers. Pyrite also associates with siliceous ferromanganese segregations. It is likely that phosphates are present. These data provide evidence of intense precipitation of many components during the first phases of concretion formation and relatively stable conditions of generation during the terminal phases.

\section{A GEOLOGICAL-GEOCHEMICAL MODEL FOR NODULE FORMATION}

A concretion is thus formed by penetration of subalkaline mineralized thermal waters of hydrocarbonate composition saturated with carbon dioxide and with sulfur-bearing gases into open cavities at the base of the hydrothermal clay mass (Fig. 11). The supply of solutions is accompanied by their boiling (degassing) 
Table 1. A description of layers and the mineral composition of concretion SKC-Zh2/19

\begin{tabular}{|c|c|c|}
\hline $\begin{array}{l}\text { Layer no., } \\
\text { thickness, } \\
\text { mm }\end{array}$ & Layer description (from inner part to periphery of concretion) & Main minerals \\
\hline $\begin{array}{c}\mathbf{1} \\
\text { Crystals up to } \\
7 \mathrm{~mm} \text { across }\end{array}$ & $\begin{array}{l}\text { Gypsum crystals. Crystal surface contains zeolite-smectite and } \\
\text { pyrite-marcasite aggregates, spongy incrustations about } 50 \times 50 \mu \mathrm{m} \\
\text { consisting of Fe and Hg sulfides (pyrite and cinnabar?) and small } \\
\text { (up to } 30 \mu \mathrm{m} \text { ) barite crystals. }\end{array}$ & $\begin{array}{l}\text { Pyrite, marcasite, cinnabar (?), zeo- } \\
\text { lites (?), smectite, gypsum, barite }\end{array}$ \\
\hline 1a, & $\begin{array}{l}\text { Siliceous ferrous layer on which gypsum crystals of layer no. } 1 \text { grow. } \\
\text { The layer has distinct boundaries. }\end{array}$ & Siliceous iron ochre \\
\hline $\begin{array}{l}2, \\
4-5\end{array}$ & $\begin{array}{l}\text { Layer with distinct boundaries. Layer groundmass is a fine-grained } \\
\text { loose aggregate of siliceous carbonate composition. Ferromanga- } \\
\text { nese (siderite-rhodochrosite?) kidney-shaped aggregates of radiate } \\
\text { columnar structure with Ca phosphate. White thin flakes of sili- } \\
\text { ceous phosphate and siliceous sulfate composition (calcium sulfates } \\
\text { and fluorine-bearing calcium phosphates) + nitrous compounds. }\end{array}$ & $\begin{array}{l}\text { Pyrite, marcasite, limonite, } \mathrm{Fe}-\mathrm{Mn} \\
\text { products, Ca phosphates, aragonite, } \\
\text { Ca sulfates, nitrogen compounds }\end{array}$ \\
\hline $\begin{array}{c}3 \\
20-45\end{array}$ & $\begin{array}{l}\text { This layer is identified in a preliminary manner. A sequence of alter- } \\
\text { nating carbonate microlayers }(1 \mu \mathrm{m} \text { to } 3 \mathrm{~mm}) \text {. Broad layers are } \\
\text { composed of fan-shaped aragonite crystals with characteristic } \\
\text { porous texture. Dispersed impregnation of pyrite in association with } \\
\text { barite. Among aragonite crystals is } \mathrm{Mn}-\mathrm{Fe} \text { carbonate associating } \\
\text { with Ca sulfates. }\end{array}$ & $\begin{array}{l}\text { Pyrite, opal, } \\
\text { F-phosphates of Ca, aragonite, sider- } \\
\text { ite, Ca sulfates, barite, nitrogen com- } \\
\text { pounds }\end{array}$ \\
\hline $\begin{array}{c}4, \\
20-35\end{array}$ & $\begin{array}{l}\text { This too is a layer with preliminary boundaries. A sequence of alter- } \\
\text { nating microlayers ( } 1 \mu \mathrm{m} \text { to } 2 \mathrm{~mm} \text { )of carbonate composition and } \\
\text { varying in color between light grey and black. The lighter and broad } \\
\text { layers are composed of columnar aragonite crystals. The prevailing } \\
\text { layers are dark, composed of massive or fine-grained aragonite. } \\
\text { Pyrite grains cluster between aragonite crystals. The layer is porous } \\
\text { (up to } 20 \% \text { of volume), pores are filled with aragonite, pyrite, barite. }\end{array}$ & $\begin{array}{l}\text { The composition is analogous to that } \\
\text { of layer no. } 3\end{array}$ \\
\hline $\begin{array}{c}\mathbf{5 a}, \\
4\end{array}$ & $\begin{array}{l}\text { The layer groundmass is carbonate. The upper surface of the layer } \\
\text { has carbonate composition with segregated incrustations which are } \\
\text { found to contain N, F, P, S, Mn, Fe, Al, and Si. Pores contain bar- } \\
\text { ite crystals. One encounters pyrite-marcasite sinter features with sil- } \\
\text { ica. Iron hydroxides and compounds of other elements make the } \\
\text { layer light brown an grey-green. }\end{array}$ & $\begin{array}{l}\text { Pyrite, marcasite, Fe hydroxides, } \\
\text { aragonite, barite, nitrogen com- } \\
\text { pounds }\end{array}$ \\
\hline $\begin{array}{c}5 \mathrm{~b}, \\
7\end{array}$ & $\begin{array}{l}\text { The layer groundmass is siliceous carbonate, fine-grained. Brown } \\
\text { silky incrustations on the surface are composed of fluorine-bearing } \\
\text { Ca phosphates. Fluorine is also encountered in the carbonate } \\
\text { groundmass. Fracture surfaces show alternating carbonate layers } \\
\text { and phosphate incrustations. There are nitrous compounds of } \\
\text { amorphous aspect, ferromanganese ochre, barite crystals. The sig- } \\
\text { nificant admixtures in the carbonate groundmass and in phosphate } \\
\text { incrustations include N, F, Cl, P, S, Na, Mg, Mn, Fe, Al, Si, Sr, Ba. }\end{array}$ & $\begin{array}{l}\text { Mineral composition is analogous to } \\
\text { that of layer } 5 \mathrm{a}\end{array}$ \\
\hline $\begin{array}{l}6, \\
2\end{array}$ & $\begin{array}{l}\text { The layer groundmass is micro-grained siliceous carbonate. The } \\
\text { inhomogeneities are composed of aragonite of acicular aspect, } \\
\text { accumulations of gypsum crystals, incrustations of F-phosphates of } \\
\mathrm{Ca} \text {, kidney-shaped aggregates of Mn carbonate, probably rhodo- } \\
\text { chrosite. Microprobe studies induce strong degassing of layer mate- } \\
\text { rial because of an abundance of volatiles. }\end{array}$ & $\begin{array}{l}\text { Limonite, F-phosphates of Ca, ara- } \\
\text { gonite, rhodochrosite (?), gypsum, } \\
\text { barite }\end{array}$ \\
\hline
\end{tabular}


Table 1. (Contd.)

\begin{tabular}{|c|c|c|}
\hline $\begin{array}{l}\text { Layer no., } \\
\text { thickness, } \\
\text { mm }\end{array}$ & Layer description (from inner part to periphery of concretion) & Main minerals \\
\hline $\begin{array}{l}7, \\
2\end{array}$ & $\begin{array}{l}\text { Grey-white incrustation composed of an aggregate of lamellar gyp- } \\
\text { sum, acicular aragonite, and silica flakes. On the incrustation sur- } \\
\text { face are kidney-shaped spongy deposits }(50-250 \mu \mathrm{m}) \text { : a mixture of } \\
\text { siliceous phosphate and siliceous carbonate composition with } \\
\text { nitrous compounds and significant concentrations of Fe and } \mathrm{Mn} \text {. }\end{array}$ & $\begin{array}{l}\text { Pyrite, marcasite, opal, aragonite, } \\
\text { Fe-Mn carbonates (siderite-rhodo- } \\
\text { chrosite?), gypsum, barite }\end{array}$ \\
\hline $\begin{array}{l}8, \\
3\end{array}$ & $\begin{array}{l}\text { An incoherent, ochrous layer. Micro-grained siliceous carbonate } \\
\text { groundmass with limonite ochre. Rare impregnations of pyrite and } \\
\text { dendrites of iron hydroxides. Scattered impregnation of barite (up to } \\
25 \mu \mathrm{m} \text { ) and clusters of lamellar gypsum crystals (?), as well as } \\
\text { incrustations of Ca phosphates with an admixture of nitrogen com- } \\
\text { pounds. }\end{array}$ & $\begin{array}{l}\text { Pyrite, limonite, F-phosphates of } \\
\text { Ca, aragonite, gypsum (?), barite, } \\
\text { nitrogen compounds }\end{array}$ \\
\hline 7-9 & $\begin{array}{l}\text { Layer with large sinter scales. The groundmass is micro-grained sili- } \\
\text { ceous carbonate and layered. Grey-whit deposits are gypsum crys- } \\
\text { tals in association with aragonite. The surfaces have a silky luster - } \\
\text { incrustations of Ca phosphates. The aragonite surface and the phos- } \\
\text { phate incrustations contain globular, kidney-shaped, radiate colum- } \\
\text { nar aggregates of rhodochrosite; abundant clusters of barite. }\end{array}$ & $\begin{array}{l}\text { Limonite, phosphates of } \mathrm{Ca} \text {, arago- } \\
\text { nite, rhodochrosite, gypsum, barite }\end{array}$ \\
\hline
\end{tabular}

Qualitative and quantitative determinations were made by E.I. Sandimirova using a VEGA 3 SEM equipped with an X-MAX 80 energy dispersive spectrometer with AZtec software at IV\&S FEB RAS under the methodological guidance of V.M. Chubarov. The objects of analysis were visible surfaces of the samples without spray-coating (layers 1, 2, 5a, 5b, 6-9) and polished sections with carbon spraycoating (layers 3 and 4). All samples show strong degassing under microprobe ray, which provides evidence of abundant volatiles in the concretion. Simultaneously, this necessitates the questions marks in this table concerning an accurate detection of mineral phases.

Table 2. The chemical composition of layers in concretion SKC-Zh2/19, wt \%

\begin{tabular}{c|l|l|l|l|l|l|l|l|l|l|l|l|l}
\hline $\begin{array}{c}\text { Layer } \\
\text { no. }\end{array}$ & $\mathrm{Si}$ & $\mathrm{Ti}$ & $\mathrm{Al}$ & $\mathrm{Fe}$ & $\mathrm{Mn}$ & $\mathrm{Ca}$ & $\mathrm{Mg}$ & $\mathrm{Na}$ & $\mathrm{K}$ & $\mathrm{P}$ & $\mathrm{LOI}$ & Sum & $\mathrm{S}$ \\
\hline 1a & 2.4 & 0.594 & 0.607 & 43.8 & 0.2 & 19.3 & 5.06 & 0.01 & 0.069 & 0.533 & 17.8 & 90.37 & 21.0 \\
2 & 0.52 & 0.021 & 0.154 & 2.66 & 0.27 & 57.1 & 0.71 & 0.133 & 0.024 & 0.083 & 39.53 & 101.2 & 2.64 \\
3 & 0.25 & 0.015 & 0.111 & 0.28 & 0.12 & 55.4 & 0.38 & 0.142 & 0.024 & 0.141 & 42.72 & 99.58 & 2.51 \\
4 & 0.173 & 0.011 & 0.085 & 0.34 & 0.1 & 54.2 & 0.321 & 0.144 & 0.025 & 0.138 & 42.71 & 98.25 & 3.01 \\
$5 \mathrm{a}$ & 0.179 & 0.01 & 0.06 & 0.72 & 0.31 & 55.1 & 0.191 & 0.138 & 0.023 & 0.124 & 42.7 & 99.56 & 2.64 \\
$5 \mathrm{~b}$ & 0.74 & 0.013 & 0.083 & 0.81 & 0.33 & 52.7 & 0.202 & 0.138 & 0.024 & 0.127 & 43.39 & 98.56 & 1.62 \\
6 & 0.255 & 0.015 & 0.068 & 0.4 & 0.35 & 54.0 & 0.2 & 0.142 & 0.024 & 0.113 & 43.49 & 99.06 & 1.62 \\
7 & 0.449 & 0.011 & 0.064 & 1.34 & 0.16 & 54.1 & 0.194 & 0.144 & 0.024 & 0.081 & 43.26 & 99.83 & 2.7 \\
8 & 0.397 & 0.022 & 0.139 & 0.89 & 0.26 & 55.3 & 0.228 & 0.141 & 0.024 & 0.113 & 43.22 & 100.7 & 2.3 \\
9 & 0.29 & 0.011 & 0.092 & 0.49 & 0.36 & 55.7 & 0.229 & 0.147 & 0.024 & 0.113 & 43.03 & 100.5 & 2.37 \\
\hline
\end{tabular}

The results were obtained at the Analytical Center of IV\&S FEB RAS using an S4 PIONEER X-ray fluorescence spectrometer. Analysts: A.A. Kuzmina, N.I. Chebrova, V.M. Ragulina. Conversion to elemental composition by E.V. Kartasheva.

and, as a consequence, by precipitation of carbonate, silicate, and ferrous gels on rock fragments. Rock fragments are the most frequent centers of growth for concretions. The crystallization of gels gives rise to colloform-banded, crustification, globular and similar structures of siliceous carbonate material. A sharp change in temperature and oversaturation of the solution relative to many compositional components leads to the following consequences: 1) growth of radiate aggregates consisting of aragonite crystals; 2) precipitation of compounds of $\mathrm{Fe}, \mathrm{Mn}, \mathrm{Ba}, \mathrm{P}$, and rare metals, and the formation of microlayers of cryptocrystalline aragonite with phosphates of $\mathrm{Ca}, \mathrm{Y}, \mathrm{Ce}$ and other elements, sulfates of $\mathrm{Ca}$ and $\mathrm{Ba}$, sulfides of $\mathrm{Fe}, \mathrm{Cu}$, and $\mathrm{Zn}$, carbonates of $\mathrm{Ca}, \mathrm{Fe}$, and $\mathrm{Mn}$, and $\mathrm{Si}-\mathrm{Fe}-$ Mn compounds. Leaching makes the solutions produce large aragonite layers in an environment of relatively quiet growth (in large cavities). Each phase of 

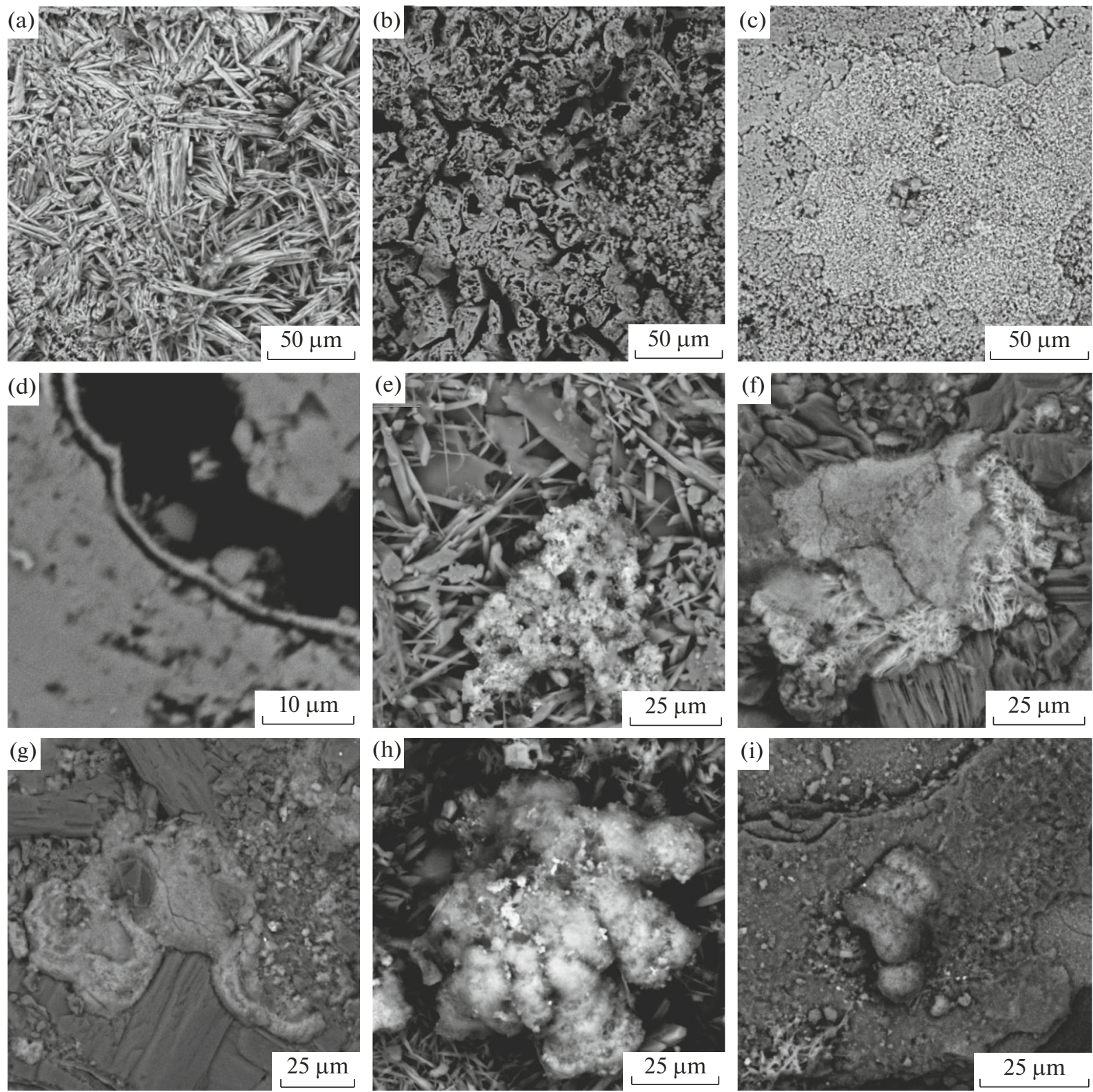

Fig. 6. The structure of fragments taken from concretion layers as obtained using a VEGA 3 SEM equipped with an X-MAX 80 energy dispersive spectrometer (IV\&S FEB RAS, Operator E.I. Sandimirova). (a) the groundmass of the carbonate layer consisting of sheaf-like, radiate and felted aggregates of aragonite crystals; (b) porous internal structure of aragonite crystals in a cross section; (c) phosphate films (the lighter spot in the middle of the image) in a carbonate groundmass; (d) phosphate films and veinlets that form between carbonate layers (polished section); (e) siliceous ferrous formations of cloddy shape, with phosphate, among aragonite crystals; (f) a complex formation consisting of a mixture of Mn and Ca carbonates (earthy mass), with an admixture of compounds of nitrogen, fluorine, silicon, and sulfur (lacy structures along the grain periphery); (g) Mn carbonate (rhodochrosite?) with an admixture of N, F, P, S, Ca and other elements; it fills the space between aragonite crystals; (h) a siliconiron-manganese kidney-shaped formation in the aragonite groundmass; (i) iron-manganese kidney-shaped formation (a globule) on a carbonate-silicon-ferrous surface.

mineral generation due to the variation of physicochemical parameters and the dynamics of incoming solutions, one observes precipitation of $\mathrm{Si}, \mathrm{Fe}, \mathrm{Mn}, \mathrm{S}$, $\mathrm{P}$ and other chemical elements, producing carbonates, sulfates, sulfides, phosphates, siliceous ferrous, ferromanganese, nitrous and other compounds. The persistent occurrence of this kind of mineral generation in many concretions tells us that open cavities are not filled with a solution once only, but that a solution with a high mineral content was supplied multiple times in a pulsating manner. In this process, the mineral content does not decrease during the entire time of concretion formation. This circumstance shows us, in turn, that there is a source of several metals (alka- 

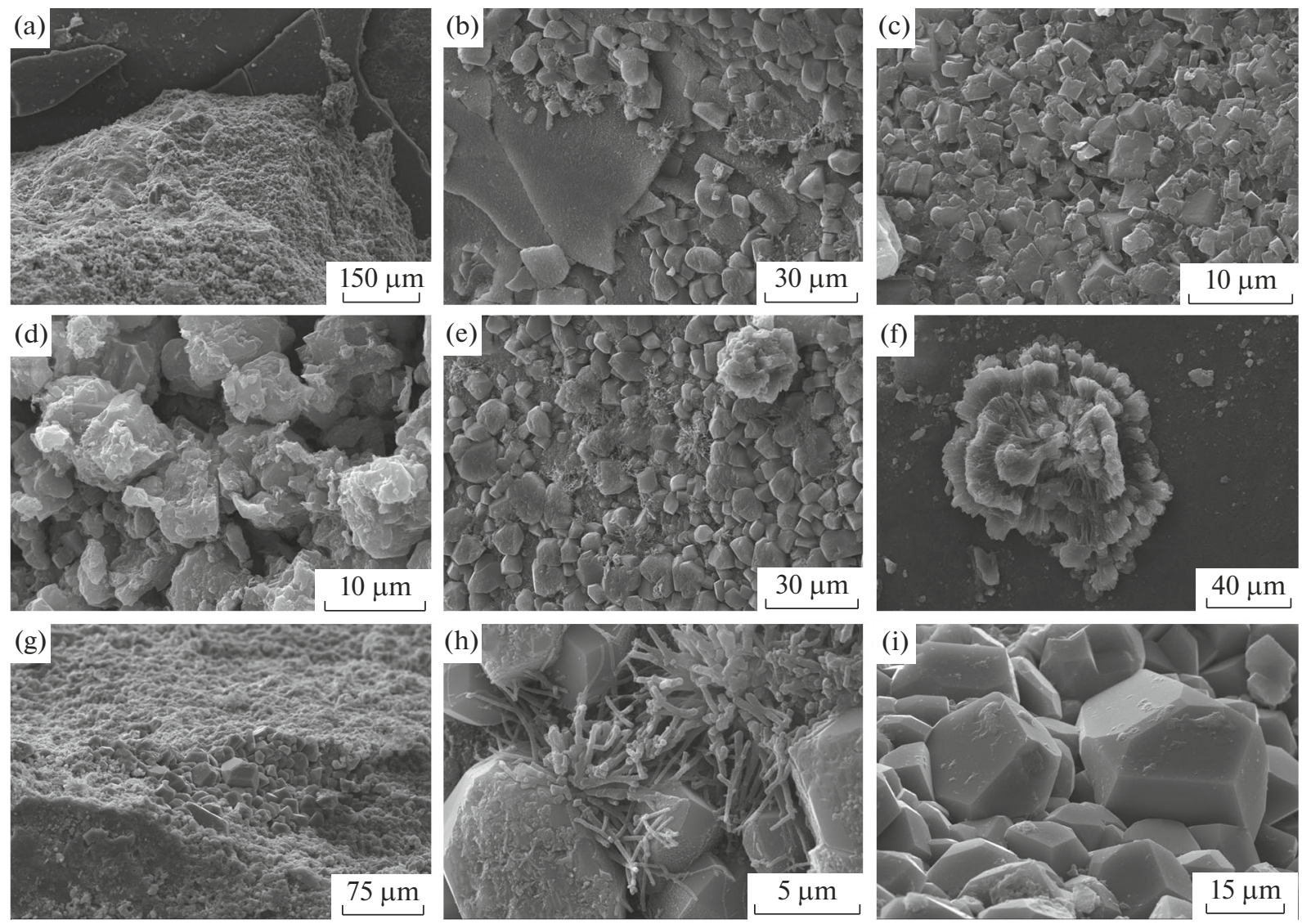

Fig. 7. The microstructure of interbeds in a carbonate concretion as revealed using a LEO 1450VP SEM equipped with an INCA 300 EDS (Faculty of Geology, Moscow State University, Operator M.S. Chernov). For explanations see main text.

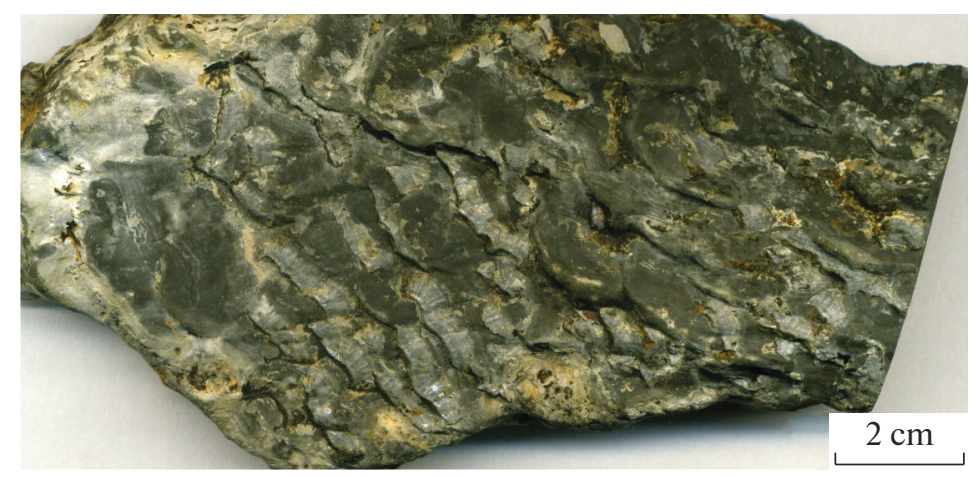

Fig. 8. The structure of the surface of the 9th layer in concretion SKC-Zh2/19: "sand dune sculpture”, after (Lebedev, 1965).

line, base, and rare metals), as well as of phosphorus and nitrogen, at some depth beneath the South Kambalnyi Central Thermal Field. Nitrogen and phosphorus are most likely of inorganic origin as mentioned here above, and are transported toward the diurnal surface as part of volcanic (geothermal) gases of aqueous gas fluids.

The formation of carbonate concretions in the South Kambalnyi Central Thermal Field shows an analogy with the formation of mineral ore associations as veins and zones at the base of the hydrothermal clay mass in the East Pauzhetka thermal field (Rychagov et al., 2017b). The paper just referred to noted the following successive alternation of mineral association (from top to bottom along the section): phosphatealumosilicate-sulfide to siliceous carbonate-sulfide to zeolite-carbonate-sulfide. Accordingly, the physico-chemical conditions of their generation were 


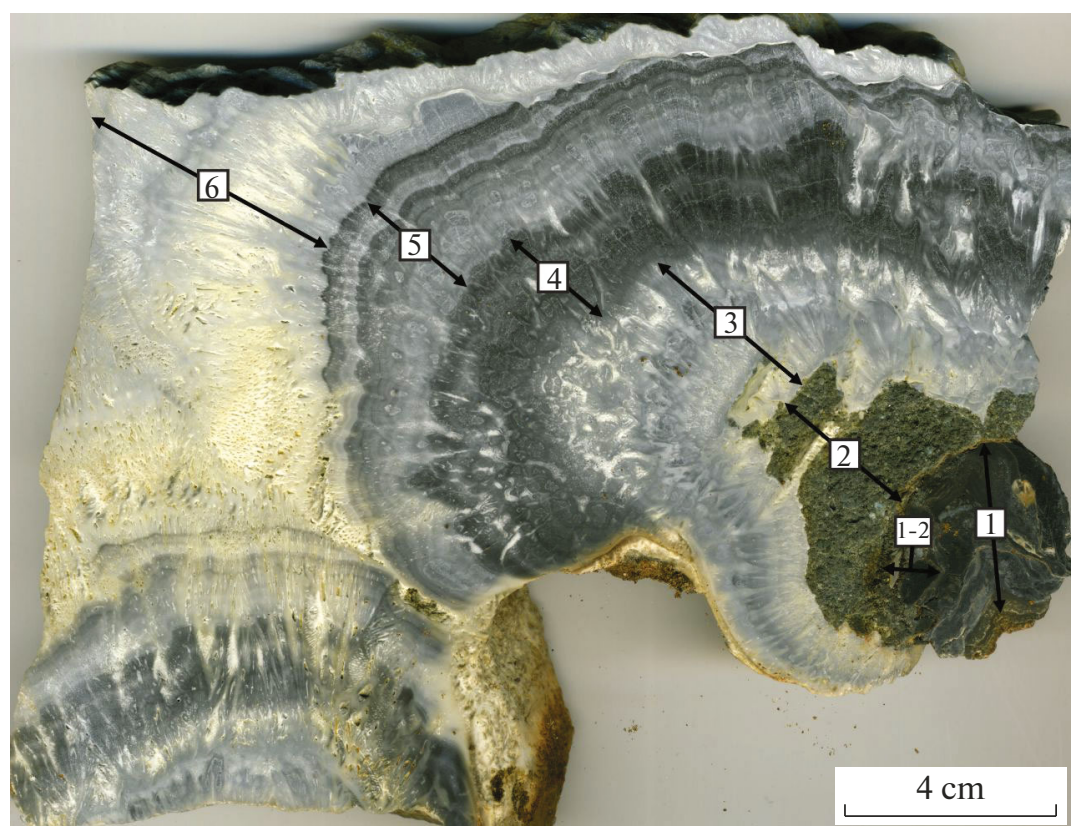

Fig. 9. Concretion SKC-Zh6/19 in a cross section. Layer numbers tally with those in Table 3.

changing from low acidic to neutral to alkaline. We thus hypothesize that the occurrence of alkaline conditions in the discharge zone of steam-charged hydrothermal fluids in the East Pauzhetka and South Kambalnyi thermal fields is due to the influence of a metalliferous fluid at depth.

\section{CONCLUSIONS}

Carbonate concretions are formed in the discharge zone of alkaline thermal water in the South Kambalnyi Central Thermal Field. The concretions were identified previously and characterized as "pseudo-globular aragonite aggregates" (Karpov, 1970). Our study has shown that these aggregates are not monomineral, we described variations in the composition and structure of concretions and put forward a geological-geochem- ical model to explain the factors that produced the complex chemical and mineral compositions of these aggregates.

The concretions are confined to one of the more active geothermal ridges in the middle of the field and seem to compose a horizon (a large lens, zone. or a similar structure) at the base of the hydrothermal clay mass. The in situ positions of the concretions have not been ascertained because of a great number of steamgas jets and hidden mud-water pots in the clay mass of this area, resulting in large cavities and open joints at the base of the mass. All of these factors made for high gas saturation, increased temperatures, and soil instabilities in the ridge area, making pitting to penetrate down to the base of the clay mass impracticable.

The concretions have complex chemical and mineral compositions and a concentrically zonal structure. In

Table 3. The chemical composition of layers in concretion SKC-Zh6/19, wt \%

\begin{tabular}{c|c|c|c|c|c|c|c|c|c|c|c|c|c}
\hline $\begin{array}{c}\text { Layer } \\
\text { no. }\end{array}$ & $\mathrm{Si}$ & $\mathrm{Ti}$ & $\mathrm{Al}$ & $\mathrm{Fe}$ & $\mathrm{Mn}$ & $\mathrm{Ca}$ & $\mathrm{Mg}$ & $\mathrm{Na}$ & $\mathrm{K}$ & $\mathrm{P}$ & $\mathrm{LOI}$ & $\mathrm{Sum}$ & $\mathrm{S}$ \\
\hline 1 & 1.57 & 0.095 & 0.674 & 2.39 & 1.35 & 54.9 & 0.603 & 0.204 & 0.048 & 0.395 & 36.97 & 99.2 & 5.84 \\
$1-2$ & 0.792 & 0.03 & 0.281 & 9.8 & 0.64 & 59.2 & 0.438 & 0.015 & 0.029 & 0.216 & 28.58 & 100.0 & 4.63 \\
2 & 21.8 & 0.773 & 7.6 & 12.4 & 0.29 & 19.1 & 3.47 & 0.038 & 0.021 & 0.244 & 19.15 & 85.2 & 6.19 \\
3 & 0.874 & 0.032 & 0.185 & 0.14 & 0.17 & 54.9 & 0.548 & 0.14 & 0.028 & 0.1 & 42.03 & 99.15 & 1.1 \\
4 & 0.073 & 0.028 & 0.185 & 0.2 & 0.01 & 56.3 & 0.402 & 0.144 & 0.03 & 0.097 & 42.66 & 100.1 & 1.48 \\
5 & 0.698 & 0.031 & 0.196 & 0.14 & 0.05 & 56.1 & 0.351 & 0.138 & 0.028 & 0.075 & 42.35 & 100.2 & 1.16 \\
6 & 0.878 & 0.031 & 0.192 & 0.11 & 0.14 & 55.9 & 0.556 & 0.142 & 0.026 & 0.085 & 42.91 & 101.0 & 1.03 \\
\hline
\end{tabular}

The results were obtained at the Analytical Center of IV\&S FEB RAS using an S4 PIONEER X-ray fluorescence spectrometer. Analysts: A.A. Kuzmina, N.I. Chebrova, V.M. Ragulina. Conversion to elemental composition by E.V. Kartasheva. 


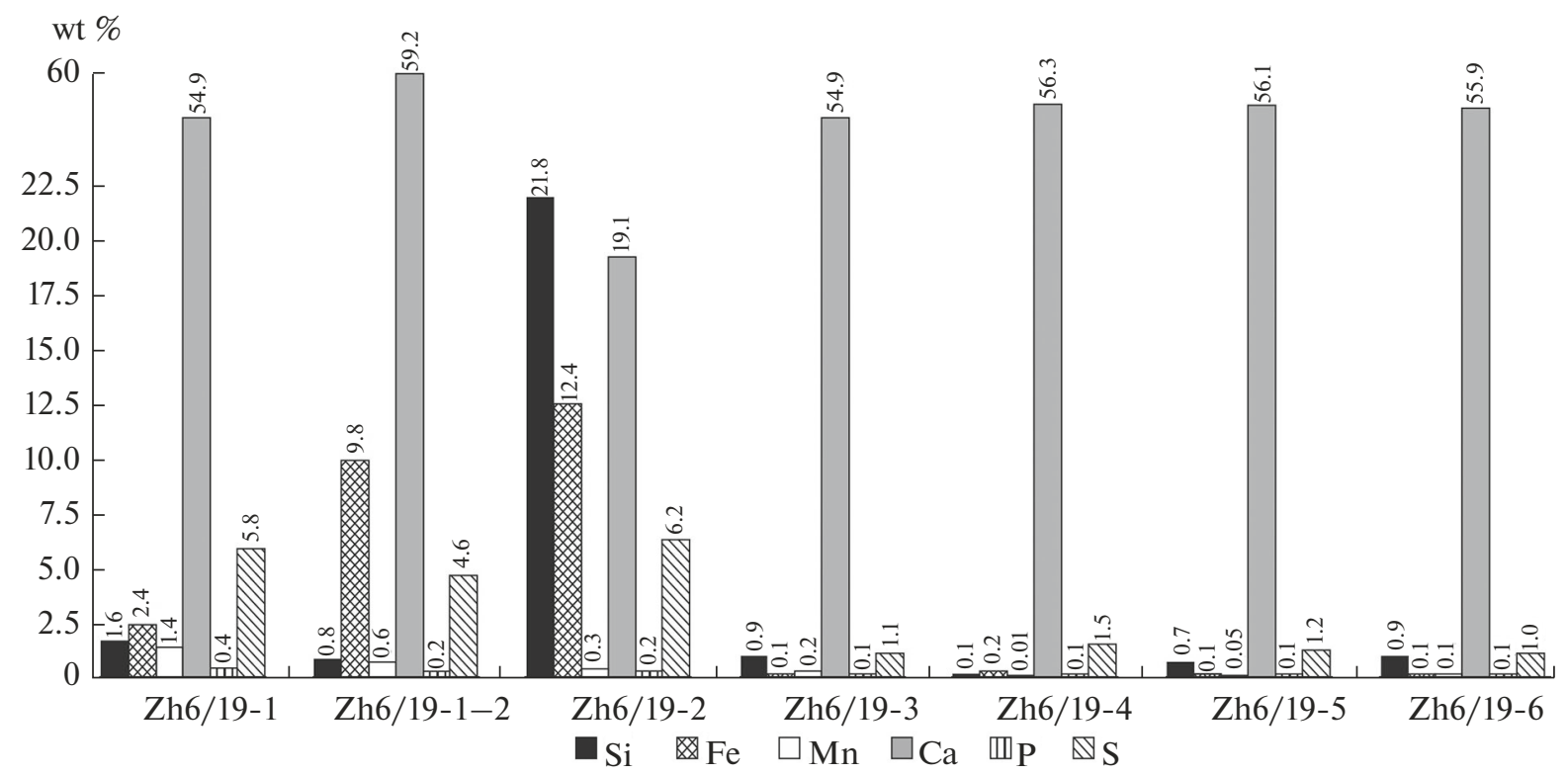

Fig. 10. The distribution of main components in the composition of layers in concretion SKC-Zh6/19 as revealed by X-ray fluorescence spectroscopy using an S4 PIONEER instrument at the IV\&S FEB RAS.

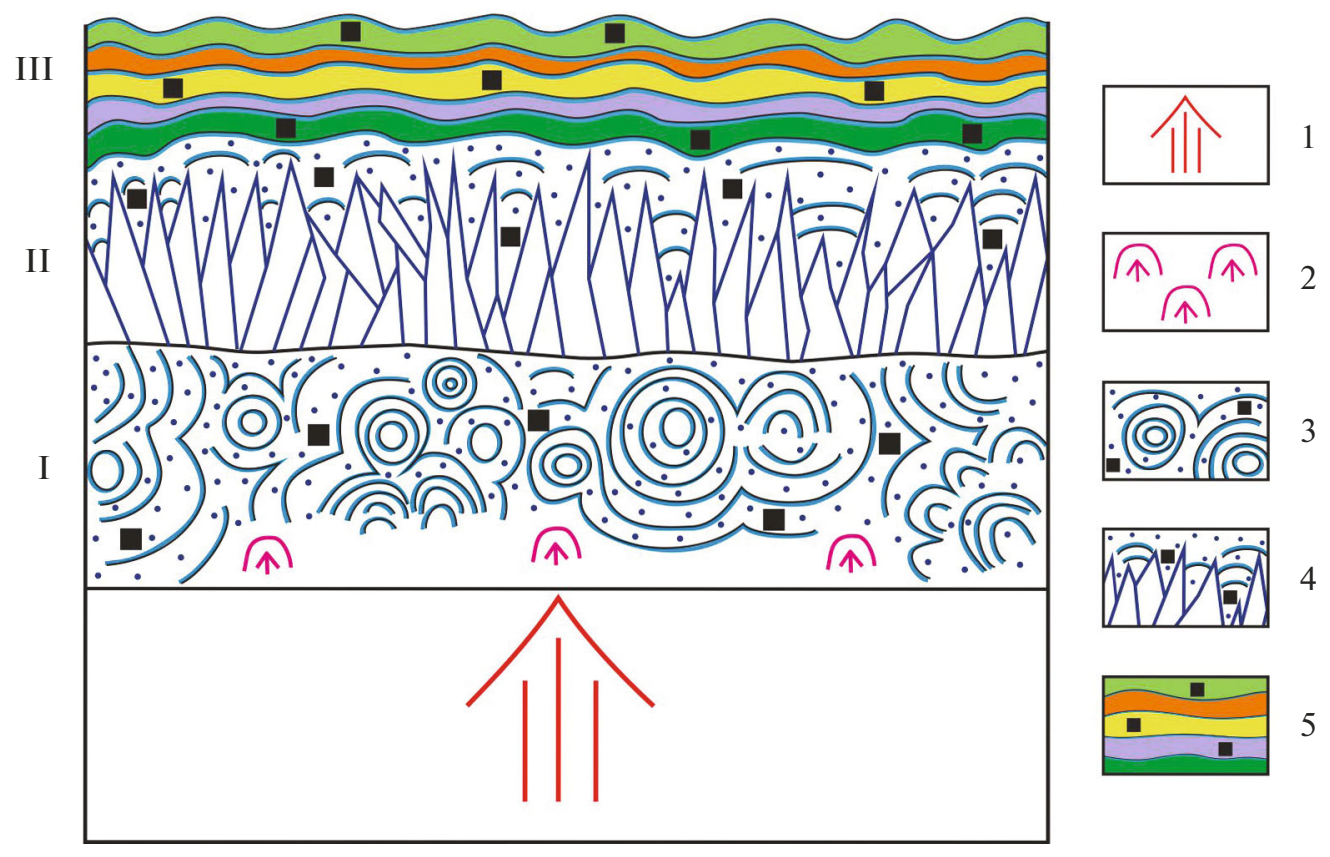

Fig. 11. A model for the formation of carbonate concretions in the South Kambalnyi Central Thermal Field. I-III are phases of mineral generation. (1) penetration of solutions into open cavities; (2) boiling of an overheated solution; (3) first phase of mineral generation (I): the formation of colloform-banded, kidney-shaped, globular and other structures, as well as of ore minerals; (4) second phase (II): the formation of large zones of aragonite composition and other mineral phases in interspaces between carbonate crystals and individual growth zones; (5) third phase (III): the formation of small and thin layers of aragonite, phosphates, silicon ferrous, silicon-iron-manganese and other mineral features.

addition to aragonite, which forms the groundmass in each zone, we have identified Fe and Si oxides, $\mathrm{Ca}$ and Ba sulfates, sulfides of Fe and other metals, Fe and Mn carbonates, $\mathrm{Si}-\mathrm{Fe}-\mathrm{Mn}$ fcompounds, as well as com- pounds of nitrogen, phosphates of calcium and rare metals. All the above mineral products make thin layers, microzones, individual flakes, kidney-shaped and globular sinters on the surface of aragonite layers. 
The carbonate concretions are characterized by diverse structures and textures: superposed upon the background of a concentrically zonal structure common to all globular aggregates one finds colloformbanded, globular, crustification, layered, massive, and radiate structures. The diversity, the definite succession and repetitiveness of the structures favor a multiphase pulsatory character of concretion formation. A more detailed explanation of the conditions and mechanism for concretion formation is proposed in the next section of this paper.

The carbonate concretions in the South Kambalnyi Central Thermal Field are thus formed by penetration of alkaline metalliferous solutions into open cavities at the base of the hydrothermal clay mass, subsequent boiling, cooling, and oversaturation of the solutions relative to the main compositional components, namely, hydrocarbonate, orthosilicic (colloid and dissolved) acid, sulfate, and ammonium. We believe that a source of several metals (alkaline, non-ferrous, and rare metals), as well as of phosphorus and nitrogen, can reside in the interior of the South Kambalnyi Central Thermal Field.

\section{ACKNOWLEDGMENTS}

We are deeply grateful to our colleagues at the South Kamchatka-Kurile Expedition, as well as to workers at the Analytical Center of IV\&S FEB RAS and at Faculty of Geology, Moscow State University for practical help in our research. This study used equipment acquired for implementing the Development Program of the Moscow State University.

\section{FUNDING}

This work was supported by the Russian Foundation for Basic Research, project no. 19-05-00102.

\section{OPEN ACCESS}

This article is licensed under a Creative Commons Attribution 4.0 International License, which permits use, sharing, adaptation, distribution and reproduction in any medium or format, as long as you give appropriate credit to the original author(s) and the source, provide a link to the Creative Commons license, and indicate if changes were made. The images or other third party material in this article are included in the article's Creative Commons license, unless indicated otherwise in a credit line to the material. If material is not included in the article's Creative Commons license and your intended use is not permitted by statutory regulation or exceeds the permitted use, you will need to obtain permission directly from the copyright holder. To view a copy of this license, visit http://creativecommons.org/licenses/by/4.0/.

\section{REFERENCES}

Atlas konkretsii (An Atlas of Concretions), Trudy DSEGEI, New Series, vol. 340, Leningrad: Nedra, 1988.

Atlas tekstur i struktur osadochnykh gornykh porod (An Atlas of Textures and Structures of Sedimentary Rocks), Part 2, Carbonate Rocks, Khabakov, A.V., Ed., Moscow: Nauka, 1969.

Baturin, G.N., Phosphorites on seamounts, Priroda, 1996, no. 8, pp. 3-13.

Belousov, V.I., Geologiya geotermalnykh polei (The Geology of Geothermal Fields), Moscow: Nauka, 1978.

Belousov, V.I., Sugrobov, V.M., and Sugrobova, N.G., The geological structure and hydrogeological features of the Pauzhetka hydrothermal system, in Gidrotermal'nye sistemy i termal'nye polya Kamchatki (The Geothermal Systems and Thermal Fields of Kamchatka), Vladivostok: DVNTs AN SSSR, 1976, pp. 23-57.

Danilov, I.D., Carbonate concretions in the subarctic Pleistocene, Izv. Akad. Nauk SSSR, Ser. Geograph., 1971, no. 5, pp. 84-94.

Dietzel, M., Dissolution of silicates and the stability of polysilicic acid, Geochim. Cosmochim. Acta, 2000, vol. 64, pp. 3275-3281.

Dolgozhivushchii tsentr endogennoi aktivnosti vulkanov yuzhnoi Kamchatki (The Long-Lived Center of Endogenous Activity of Southern Kamchatka Volcanoes), Masurenkov, Yu.P., Editor-in-Chief, Moscow: Nauka, 1980.

Eroshchev-Shak, V.A., Gidrotermal'nyi subpoverkhnostnyi litogenez Kurilo-Kamchatskogo regiona (The Hydrothermal Subsurface Lithogenesis in the Kuril-Kamchatka Region), Moscow: Nauka, 1992.

Feofilaktov, S.O., Nuzhdaev, I.A., and Denisov, D.K., The structure of the discharge zone in the South Kambalnyi Central Thermal Field as inferred from geophysical data, southern Kamchatka, in Materialy XXIII nauchnoi konferentsii, posvyashchennoi Dnyu vulkanologa (Proc. XXIII conference devoted to Volcanologist's Day), March 30-31, 2020, Petropavlovsk-Kamchatsky: IViS DVO RAN, 2020, pp. 227-230.

Froelich, P.N., Bender, M.L., Luedtke, N.A., et al., The marine phosphorus cycle, Amer. J. Sci., 1982, vol. 282, no. 4, pp. 474-511.

Frolova, Yu.V., Rychagov, S.N., Chernov, M.S., et al., Engineering geological aspects of the alteration of volcanogenic rocks in the zone of acidic leaching in the South Kambalnyi thermal fields, southern Kamchatka, Inzhenern. Geol., 2020, vol. 15, no. 1, pp. 36-51.

Geologicheskii slovar (Geological Dictionary), Moscow: Nedra, 1973, vol. 1, pp. 351-352.

Girina, O.A., Melnikov, D.V., Manevich, A.G., and Nuzhdaev, A.A., The 2017 eruption of Kambalnyi Volcano, in Sovremennye problemy distantsionnogo zondirovaniya Zemli iz kosmosa (Current Problems in Remote Sensing of the Earth from Space), 2017, vol. 14, no. 2, pp. 263267.

Gorbunova, L.I., Carbonate and phosphate concretions in the Lower Cretaceous deposits of the northeastern Caucasus, Byull. MOIP, Otd. Geologii, 1958, vol. XXXIII, no. 5, pp. $123-141$. 
Granina, L.Z., Mats, V.D., and Fedorin, M.A., Ferromanganese rocks in the region of Lake Baikal, Geol. Geofiz., 2010, vol. 51, no. 6, pp. 835-848.

Karpov, G.A., Pseudo-circular aggregates of aragonite in the present-day thermal field of the Kambalnyi Range, Kamchatka, in Mineralogiya gidrotermalnykh sistem Kamchatki i Kurilskikh ostrovov (The Mineralogy of Hydrothermal Systems: Kamchatka and the Kuril Islands), Moscow: Nauka, 1970, pp. 157-165.

Kolesnik, O.N. and Astakhova, N.V., Grains of base and noble metals in ferromanganese formations and magmatic rocks in the undersea uplifts of the Japan Sea, Okeanologiya, 2018, vol. 58, no. 1, pp. 80-88.

Kolesnik, O.N. and Kolesnik, A.N., The chemical and mineral composition of ferromanganese concretions in the Chukchi Sea, Geol. Geofiz., 2013, vol. 54, no. 7, pp. 853-866.

Krasnov, S.G., Major sulfide deposits in the ocean, Priro$d a, 1995$, no. 2, pp. 3-14.

Lebedev, L.M., Metakolloidy v endogennykh mestorozhdeniyakh (Metacolloids in Endogenous Deposits), Moscow: Nauka, 1965.

Manceau, A., Kersten, M., Marcus, M.A., et al., Ba and Ni speciation in a concretion of binary Mn oxide phase composition from Lake Baikal, Geochim. Cosmochim. Acta, 2007. V. 71. P. 1967-1981.

Nekhoroshev, A.S., Hydrothermal activity in the area of the Kambalnyi Range in southern Kamchatka, Byull. Vulkanol. St., 1959, no. 28, pp. 23-32.

Ogorodova, A.S., The hydrothermal process in a zone of acidic leaching, in Gidrotermalnye mineraloobrazuyushchie rastvory oblastei aktivnogo vulkanizma (Hydrothermal Mineral-Generating Solutions in Areas of Active Volcanism), Novosibirsk: Nauka, 1974, pp. 173-184.

Pampura, V.D., Geokhimiya gidrotermalnykh sistem oblastei sovremennogo vulkanizma (The Geochemistry of Hydrothermal Systems in Areas of Present-Day Volcanism), Novosibirsk: Nauka, 1985.

Pauzhetskie goryachie vody na Kamchatke (The Pauzhetka Hot Waters in Kamchatka), Moscow: Nauka, 1965.

Rychagov, S.N., Sandimirova, E.I., Sergeeva, A.V., and Nuzhdaev, I.A., The composition of the ash ejected by Kambalnyi Volcano (the 2017 eruption), Vestnik KRAUNTs, Nauki o Zemle, 2017a, no. 4, no. 36, pp. 1327.

Rychagov, S.N., Sergeeva, A.V., and Chernov, M.S., Mineral associations at the base of a clay mass as indicators of fluid regime in the Pauzhetka Hydrothermal System, Kamchatka, Tikhookean. Geol., 2017b, vol. 36, no. 6, pp. 90-106.

Rychagov, S.N., Kravchenko, O.V., Nuzhdaev, A.A., et al., The South Kambalnyi Central Thermal Field: The Structural setting, hydrogeochemical and lithologic characteristics, in Materialy XXIII nauchnoi konferentsii, posvyashchennoi Dnyu vulkanologa (Proc. XXIII conference devoted to Volcanologist's Day),
March 30-31, 2020, Petropavlovsk-Kamchatsky: IViS DVO RAN, 2020a, pp. 198-201.

Rychagov, S.N., Sandimirova, E.I., and Kartasheva, E.V., Carbonate concretions in the South Kambalnyi Central Thermal Field, southern Kamchatka, in Materialy XXIII nauchnoi konferentsii, posvyashchennoi Dnyu vulkanologa (Proc. XXIII conference devoted to Volcanologist's Day), March 30-31, 2020, Petropavlovsk-Kamchatsky: IViS DVO RAN, 2020b, pp. 202-205.

Saltykov, V.F., Carbonate concretions in the Middle Jurassic section of the lower Volga R. reaches, Izvestiya Saratovskogo Universiteta, Ser. Nauki o Zemle, 2008, no. 1, pp. 64-75.

Skiba, N.S., Celestine concretions in the Fergana Upper Cretaceous deposits, Zapiski Kirgiz. Otdel. VMO, 1963, no. 4, pp. 69-94.

Sletov, V.A., The morphology of cherty bodies in the carbonate rocks of Moscow Region and their genesis, in Novye dannye o mineralakh SSSR (New Data on Minerals in the USSR), Moscow: Nauka, 1977, no. 26, pp. 112-119.

Strakhov, N.M., The localization of ore concretions of Fe and $\mathrm{Mn}$ in the Pacific Ocean and its genetic significance, Litologiya Polezn. Iskopaemye, 1974, no. 5, pp. 3-17.

Struktura gidrotermalnoi sistemy (The Structure of Hydrothermal Systems), Moscow: Nauka, 1993.

Sugrobov, V.M., Geothermal reserves of Kamchatka, classification and forecast, in Izuchenie i ispol'zovanie geotermal'nykh resursov $v$ vulkanicheskikh oblastyakh (The Study and Use of Geothermal Reserves in Volcanic Areas), Moscow: Nauka, 1979, pp. 26-35.

Syvorotkin, V.L., The present-day volcanism in southern Kamchatka and the hydrothermal process, in Struktura gidrotermal'noi sistemy (The Structure of Hydrothermal Systems), Moscow: Nauka, 1993, pp. 19-38.

Vetoshkina, O.S., Siderite biomorphs in Jurassic deposits in the Nizhnyaya Vychegda basin of the northern Russian plate, Dokl. Akad. Nauk, 2006, vol. 406, no. 5, pp. 663667.

Zavarzin, G.A., Chemosynthesis and anorgoxidation, Uspekhi Mikrobiologii, no. 1 (A separate print), Moscow: Nauka, 1964, pp. 30-60.

Zavarzin, G.A. and Karpov, G.A., The role of bacterial factors in the present-day mineral generation in the Uzon Caldera, Dokl. Akad. Nauk SSSR, 1982, vol. 264, no. 1, pp. 244-247.

Zhelezo-margantsevye konkretsii Tsentralnoi kotloviny Indiiskogo okeana (Ferromanganese Concretions in the Central Basin of the Indian Ocean), Moscow: Nauka, 1989.

Zhelezo-margantsevye konkretsii tsentralnoi chasti Tikhogo okeana (Ferromanganese Concretions in the Central Pacific Ocean), Moscow: Nauka, 1986.

Translated by A. Petrosyan 